\title{
Role of Ethrel and Storage in Dormancy Breaking in Groundnut (Arachis hypogaea L.)
}

\author{
Deepthi Rajan $^{1^{*}}$, Rajiv Kumar ${ }^{2}$, K. Devyani ${ }^{3}$ and M. J. Ramya ${ }^{3}$ \\ ${ }^{1}$ Department of Seed science and Technology, ${ }^{2}$ Department of Genetics and Plant Breeding, \\ ${ }^{3}$ College of Agriculture, Junagdh Agricultural University, \\ Junagadh - 362001 (Gujarat), India \\ *Corresponding author
}

\section{Keywords}

Groundnut seed dormancy, Genotypes, Ethrel concentrations, Storage periods

Article Info

Accepted:

18 January 2020

Available Online:

10 February 2020

\section{A B S T R A C T}

Experiment was conducted to evaluate the effect of different ethrel concentrations and storage periods on dormancy breaking in groundnut. Control $\left(\mathrm{C}_{1}\right)$ and three ethrel concentrations; $\mathrm{C}_{2^{-}}-25 \mathrm{ppm}, \mathrm{C}_{3}-50 \mathrm{ppm}, \mathrm{C}_{4^{-}}-75 \mathrm{ppm}$ were evaluated for four different storage periods; $S_{1}-7$ days after harvest, $S_{2}-14$ days after harvest, $S_{3}-21$ days after harvest and $\mathrm{S}_{4}-28$ days after harvest in freshly harvested groundnut dormant varieties, GG-11 and GG-20 and compared their performance with that of non-dormant variety, GG-7. The observations were recorded on seed germination (\%), Speed of germination, seed vigour index-I and seed vigour index-II. The results of investigation revealed that absence of dormancy in GG-7 triggering it to reap superior results immediately in all seed quality parameters studied. All ethrel treatments gave better results when compared to control (no treatment) in breaking seed dormancy and improving seed quality parameters. With increase in ethrel concentration the responses also got improved with best always from ethrel concentration@ 95 ppm. In case of dormant genotypes, dormancy was broken and performance of seed quality parameters was driven to the level of non-dormant genotype whereas non-dormant genotype had done betterment in its performance under the influence of ethrel treatments. In case of storage study it was observed that the advancement in storage period broke seed dormancy more effectively along with improvement in seed quality parameters. Thus, from the results of the study, it seems quite logical to note that the seeds kept in storage for a period of 28 days after harvest and pre-soaked in $75 \mathrm{ppm}$ ethrel concentration can effectively broke the seed dormancy and can improve all the seed quality parameters as well to a performance level that can equate with that of non-dormant genotype.

\section{Introduction}

Groundnut (Arachis hypogaea L.) is a member of the order Fabales and family Fabaceae. It is a widely grown annual crop with self-pollinated and dicotyledonous behaviour also known in the names of peanut, earthnut, goober pea, goober, pindas, jack nut, manila nut, pygmy nut, pignut, and monkey nut. Groundnut is the $13^{\text {th }}$ most important food crop and $4^{\text {th }}$ most important oilseed crop of the world. Groundnut is 
cultivated in tropical, sub-tropical and warm temperate regions between $40^{\circ} \mathrm{N}$ and $40^{\circ} \mathrm{S}$ latitudes. The production is largely restricted to Asian and African countries with China, India, Nigeria, Senegal, Sudan, Burma and the United States of America are the major producers. In India six states namely Andhra Pradesh, Gujarat, Karnataka, Maharashtra, Rajasthan and Tamil Nadu account for about $90 \%$ of the total groundnut area of the country.

Seed dormancy has been defined as the failure of an intact, viable seed to complete germination under favourable conditions (Bewley, 1997). It is a state of arrested development or physiological activity of seed.Studies by several workers indicated that seeds of Spanish and Valencia bunch types of groundnut are usually non dormant, whereas those of Virginia types are dormant (Bhapkar et al., 1986). Dormancy periods up to two months is observed in Virginia type cultivars. This makes the freshly harvested seeds of Virginia type of summer season unavailable for cultivation immediately in the following kharif season. Seed dormancy is also a problem for plant breeders going for advancing pedigree lines in off-season. Similarly the seed analyst faces difficulty in determining germination potential of seed samples having dormancy. In groundnut, seed dormancy has been reported to be controlled by two hormones: abscisic acid which inhibits sprouting and ethylene which is accumulated in embryonic axis during storage to break dormancy to allow germination (Ketring and Morgan, 1971, 1972). In another study Nautiyal et al., (1993) found different parts of groundnut seed being involved in imposing dormancy, which included the seed coat, cotyledons and embryo.

Ethylene, supplied either directly as gas or by means of an ethylene generating chemical such as ethrel or ethephon, has been found to break dormancy in several species. The effective concentrations are in the range of 10-200 ppm. During germination, ethylene appears to have two roles; it can break seed dormancy in some species and reduce the time required for radicle emergence in nondormant seeds. These two activities are probably related to making the seeds less sensitive to abscisic acid, which keeps the seeds dormant (Ketring and Morgan, 1972). Another factor that can be used effectively for overcoming dormancy problem is storage. In most of the crop species, dormancy is dissipated within a few to several months when the seed is stored at ambient temperatures and relative humidity or under controlled atmosphere provided the temperature is held above freezing. In the view of the above, present investigation was undertaken to assess the effect of different varieties, ethrel concentrations and storage periods in breaking seed dormancy in groundnut and how they influences various seed quality parameters.

\section{Materials and Methods}

The experiment was conducted in laboratory of Seed Science and Technology, JAU, Junagadh from $23^{\text {rd }}$ October to $5^{\text {th }}$ December2017 in four replications. Control $\left(\mathrm{C}_{1}\right)$ and three ethrel concentrations; $\mathrm{C}_{2}-25 \mathrm{ppm}, \mathrm{C}_{3}-50$ $\mathrm{ppm}, \mathrm{C}_{4^{-}} 75 \mathrm{ppm}$ were evaluated for four different storage periods; $S_{1}-7$ days after harvest, $S_{2}-14$ days after harvest, $S_{3}-21$ days after harvest and $\mathrm{S}_{4}-28$ days after harvest in freshly harvested dormant varieties, GG-11 and GG-20 and compared their performance with that of non-dormant variety, GG-7.The observations were recorded on seed germination (\%), Speed of germination, seed vigour index-I and seed vigour index-II.

\section{Statistical analysis}

The statistical data was analyzed by the FCRD methods as per the procedure given by Cochran and Cox. Data of seed germination 
(\%) was transformed as per arc sine transformation and Speed of germination, seed vigour index-I and seed vigour index-II data were transformed as per square-root transformation (Gomaze and Gomaze).

\section{Results and Discussion}

The effect of varieties, ethrel concentrations, storage periods, interaction effect of varieties $x$ ethrel concentrations, interaction effect of varieties $\mathrm{x}$ storage periods, interaction effect of ethrel concentrations $\mathrm{x}$ storage periods and interaction effect of varieties $\mathrm{x}$ ethrel concentrations $\mathrm{x}$ storage periods were found significant for seed germination percentage, speed of germination, seed vigour index-I \& II.

\section{Effect of varieties}

The results presented in Table 1 revealed that different varieties exerted significant effect on seed germination (\%). Both dormant varieties recorded poor germination percentage with lowest marked by GG-20 $\left(\mathrm{V}_{3}\right) \quad[55.1 \%$ $(65.9 \%)]$ while the non-dormant variety GG-7 $\left(\mathrm{V}_{1}\right)$ obtained significantly highest germination percentage $[71.4 \% \quad(88.8 \%)]$. Germination percentage showed significant variation between the non-dormant variety GG-7 and dormant varieties (GG-11and GG20). But there wasn't any significant variation between these two dormant varieties. Moreover this result also revealed a very clear differentiation in germination per cent between dormant and non- dormant varieties where both the dormant varieties recorded with lowest germination per cent when compared to the non-dormant GG-7. Similar results were obtained by Nautiyal et al., (1996), Mather and Manivel (2000), Manonmani (2002), Swain et al., (2002) and Asibuo et al., (2008) in groundnut. Actual reason behind variation in germination per cent related to dormancy is stated differently by different researchers. Hull (1937) reported that dormancy in groundnut is an inherent character and the rest period extended even upto two years in some varieties. John et al., (1948) reported that dormancy is an inherent property of Virginia groundnut. Ketring and Morgan (1971) reported that the embryonic axis of non-dormant seeds of peanut actively produced ethylene during germination, whereas ethylene production was low in dormant seeds which might have promoted dormancy. Unlike in bunch groundnut, high content of growth inhibitors was noticed in the embryonic axis and the seed coat of dormant seeds of spreading groundnut. In addition to this inhibitory phenolic acid, particularly coumarin was present at highest levels in the dormant seeds of spreading groundnut. On the contrary, higher levels of synergistic phenolic acids, low level of coumeric acid was noticed in the nondormant seeds of bunch groundnuts (Sreeramulu, 1974). Reddy and Swamy, (1979) reported that at the time of maturity, dormant seeds contained greater amount of ABA- like inhibitors and less cytokinins than non-dormant seeds.

The results presented in Table 2 revealed that significant differences existed for speed of germination among different varieties. Nondormant GG-7 $\left(\mathrm{V}_{1}\right)$ recorded significantly highest speed of germination [8.7 (75.9)] and least was recorded by dormant variety GG-20

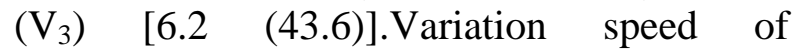
germination between dormant and nondormant varieties were very clear with both the dormant varieties recorded with lowest values when compared to the non-dormant GG-7. Unlike germination percentage, here significant variation existed between the dormant varieties (GG-11 and GG-20) with highest result obtained by GG-11 for speed of germination. Varietal differences in this parameter may be contributed from their genetic makeup. This result was in 
accordance with the results obtained by Mahesh, (2007) in groundnut and Sebastian, (2014) in proso millet and foxtail millet.

The results displayed in Table 3 and Table 4 revealed that significant differences existed among varieties for seed vigour index-I and seed vigour index-II. Non-dormant GG-7 ( $\left.\mathrm{V}_{1}\right)$ displayed significantly highest seed vigour index-I [30.1 (910.0)] and vigour index-II [114.8 (13058.0)]. Lowest result was given by GG-20 $\left(\mathrm{V}_{3}\right)$ for vigour index-I [21.7 (539.9)] which was at par with GG-11 $\left(\mathrm{V}_{2}\right)$ [22.0 (536.7)] and vigour index-II [84.9 (8350.0)].Varieties had shown significant variation for seed vigour index-I and seed vigour index-II. Even though significant differences were not there between dormant varieties, prominent variation existed between dormant varieties (GG-11 and GG-20) and non-dormant GG-7 revealing the role of dormancy in determining the seed vigour index. These results were in accordance with the findings of Mahesh, (2007) in groundnut, Adebisi and Ajala (2007); Sebastian, (2014) in prosomillet and foxtail millet.

\section{Effect of ethrel concentration}

The results presented in Table 1 revealed that different levels ethrel concentration exerted significant effect on seed germination $(\%)$. Pre-soaking of seeds in ethrel solution induced significant improvement in germination when compared to control $\left(\mathrm{C}_{1}\right)$ [39.7\% (45.1\%)]. Among the three ethrel treatments, ethrel @ 75ppm $\left(\mathrm{C}_{4}\right)$ resulted in significantly maximum germination percentage $[73.1 \%(90.1 \%)]$ and minimum was recorded with ethrel @ 25 ppm $\left(\mathrm{C}_{2}\right)$ [61.2\% (74.9\%)]. All the ethrel treatments improved the germination above Indian Minimum Seed Certification Standards (IMSCS-70\%) while control had fallen far below of standard germination due to the presence of dormancy. Françoise et al.,
(2014) reported dormancy can be regulated by the hormonal balance between abscisic acid and gibberellins where ethylene plays a key role in dormancy release and based on studies using inhibitors of ethylene biosynthesis and analysis of mutant lines altered in genes involved in the ethylene signaling pathway (etr1, ein2, ain1, etr1, and erf1) demonstrated the involvement of ethylene in the regulation of germination and dormancy. Similar results were also obtained by Wang et al., (2012) in groundnut and he reported that inhibitors present in seed coat may be inducing dormancy. John et al., (1948), Toole et al., (1961), Ketring and Morgan, (1971), Gowda, (2014) also stated the same opinion in breaking groundnut seed dormancy and improving germination per cent. During germination, ethylene appears to have two roles. Ethylene can break seed dormancy in some species. It can also reduce the time required for radicle emergence in nondormant seeds. These two activities are probably related to making the seeds less sensitive to abscisic acid, which keeps the seeds dormant (Ketring and Morgan, 1972). Ethylene treatment requires less time and it is effective at low concentrations and at usual seed-germinating temperatures. Maiti et al., (2006) reported that the causal mechanism for breaking dormancy induced by chemical treatments might be due to some chemical changes in the seed during the change from solution to gel stage by soaking and drying process. This might be associated with the washing away of inhibitors like ABA and further during the process, the porosity of the seed coat might have increased and resulted in increases germination per cent.

The results presented in Table 2 revealed that different levels ethrel concentration resulted in significant effect on speed of germination. Ethrel @ 75 ppm $\left(\mathrm{C}_{4}\right)$ recorded significantly highest [8.3 (69.6)] speed of germination and lowest speed of germination was displayed by 
control $\left(\mathrm{C}_{1}\right)$ [4.9 (31.4)]. All the ethrel treatments promoted fast germination when compared to control and also increase in ethrel concentration significantly improved speed of germination. Dormancy is a condition that prevents seeds from germination even though they are viable and provided with optimum conditions for germination. Ethylene gas at low concentrations directly related with initiation of reactions required for converting the quiescent cells to an active state of growth. Ethylene production by seeds begins immediately after the onset of imbibition and increases with time of germination and this endogenous production accompanies the natural decline of dormancy. Exogenously applied ethylene can intervene gradual breaking of dormancy and can accelerate that process (Ketringand Morgan, 1971). Gowda, (2014) in groundnut and Sebastian, (2014) in prosomillet and foxtail millet obtained similar results.

The results presented in Table 3 and 4 revealed that different levels ethrel concentration exerted significant effect on seed vigour index-I and II respectively. Ethrel @ 75 ppm $\left(\mathrm{C}_{4}\right)$ recorded highest seed vigour index-I [28.9 (839.8)] and vigour index-II [113.6 (12965.0)]. Lowest was observed in control $\left(\mathrm{C}_{1}\right)$ for both vigour index-I [17.0 (388.9)] and vigour index-II [65.2 (5794.0)]. Seed vigour index-I and seed vigour index-II were significantly improved by ethrel treatments and among them ethrel @ 75 ppm gave most promising results followed by rest of the two treatments leaving control far behind.Here also as described earlier the hormonal interactions between ethylene and gibberellins influenced by the external application of ethylene producing compounds might have induced $\mathrm{GA}_{3}$ which activate $\alpha$ amylase that can digest the available carbohydrates into simple sugar so that energy and nutrition were easily available to faster growing seedlings (Françoise et al., 2014). This might have promoted seedling dry weight and thus the seed vigour index. More over the enhancement in germination percentage by ethrel treatments also paved way for obtaining higher results in seed vigour index. Gowda, (2014) in groundnut, Meharunnisa et al., (2012) in sunflower, Sebastain, (2014) in prosomillet and foxtail millet got similar results.

\section{Effect of storage periods}

The results presented in Table 1 revealed that different storage periods significantly effected on seed germination (\%). Germination percentage increased with advancement of storage periods. Significantly highest germination percentage was recorded at 28 days after harvest $\left(\mathrm{S}_{4}\right) \quad[68.7 \% \quad(84.8 \%)]$ whereas the lowest seed germination percentage was recorded at initial storage period, 7 days after harvest $\left(S_{1}\right)$ [49.6\% $(59.1 \%)]$. Existence of fresh seed dormancy in groundnut seeds which require resting period for breaking it might have resulted in low germination percentage during initial storage periods and with the advancement in storage period, parameter improved and fetched maximum result at final stage of storage due to natural breakdown of dormancy. Similar results are also obtained by Sreeramulu, (1974) reported that decrease in inhibitory phenolic acid and increase in synergistic one in both cotyledons and embryonic axis, as storage period advanced resulted in breaking dormancy. Nautiyal et al., (1993) reported that the degree of maturity, position of kernel in the pod and the storage period all had a confounding influence on the seed dormancy.

The results presented in Table 2 revealed that different storage periods exerted significant effect on speed of germination. Significantly highest speed of germination was recorded at 
the final stage of storage period $\left(\mathrm{S}_{4}\right) 28$ days after harvest [8.1 (66.3)] whereas the lowest was recorded at initial stage $\left(\mathrm{S}_{1}\right) 7$ days after harvest $[5.9(42.8)]$. This variation may be due do the existence of fresh seed dormancy in groundnut seeds which require resting period for breaking it and to advance to better germination. The slow release of this dormancy may be the reason behind betterment of speed of germination over storage period.

The results presented in Table 3 and Table 4 revealed that different storage periods exerted significant effect on seed germination (\%).With the advancement in storage period an increasing tendency was observed for seed vigour index-I \& II. Significantly highest seed vigour index-I [26.9 (736.0)] and seed vigour index-II [106.1 (11458.0)] was recorded at 28 days after harvest $\left(\mathrm{S}_{4}\right)$. Minimum vigour index value was recorded at 7 days after harvest $\left(\mathrm{S}_{1}\right)$ for vigour index-I [21.2 (562.5)] and vigour index-II [80.1 (8075.0)]. Improvement in parameters along storage period may be contributed by the release of dormancy during storage

\section{Interaction effect of varieties $x$ ethrel concentration}

In case of interaction effect of the varieties and ethrel concentration, maximum germination percentage was obtained by the non-dormant GG-7 pre-soaked in 75 ppm of ethrel solution $\left(\mathrm{V}_{1} \mathrm{C}_{4}\right)$ [76.3\% (94.2\%)] and minimum by dormant GG-20 in control $\left(\begin{array}{lll}\left.\mathrm{V}_{3} \mathrm{C}_{1}\right) & {[23.2 \%} & (20.5 \%)] . \text { Endogenous }\end{array}\right.$ production of ethylene accompanies the natural decline of dormancy, so that exogenously applied ethylene can intervene in the gradual breaking of dormancy and can accelerate that process. When this property of different ethrel concentrations combined with three different varieties with that might have different genetic makeup for the control of dormancy, significant variations produced in their interactions. Similar results were obtained by Wang et al., (2012) for germination percentage, in which they explained significant differences in interaction may be due differential sensitivity of groundnut varieties for ethrel treatments. Maity et al., (2006) also obtained significant interaction effect between sunflower varieties and ethrel treatments for germination percentage.

Maximum speed of germination was scored byGG-7 treated with $75 \mathrm{ppm}$ of ethrel solution $\left(\mathrm{V}_{1} \mathrm{C}_{4}\right)[9.1(82.3)]$ and it was at par with ethrel @ 50 ppm treated GG-7 itself $\left(\mathrm{V}_{1} \mathrm{C}_{3}\right)$ [8.9 (78.3)]. Minimum speed of germination was recorded by GG-20 under control $\left(\mathrm{V}_{2} \mathrm{C}_{1}\right)$ [2.6 (8.5)]. Irrespective of varieties in all interactions ethrel treatments resulted in significant improvement in speed of germination when compared to control and among them ethrel @ 75 ppm gave most superior result followed by $50 \mathrm{ppm}$ and then $25 \mathrm{ppm}$ in all varieties. In case of nondormant variety GG-7, all the ethrel treatments promoted in more betterment of all the parameter. While in case of dormant varieties these treatments effectively broke the existing seed dormancy and increased their performance to the level of non-dormant variety.

Maximum significant increase in seed vigour index-I as well as vigour index-II was marked by GG-7 treated ethrel @ 75 ppm $\left(\mathrm{V}_{1} \mathrm{C}_{4}\right)$ [31.8 (1014.9) and 119.5 (14292.0)] respectively. Minimum result was obtained by GG-20 under control $\left(\mathrm{V}_{3} \mathrm{C}_{1}\right)$ for vigour indexI [10.0 (148.1)] and [37.9 (2168.0)].All ethrel treatments resulted in mostly significant improvement from control and preceding concentration irrespective of varities. At a particular ethrel concentration it was the nondormant GG-7 recorded maximum results. Ethrel treatments effectively broke the 
existing seed dormancy and increased the performance of dormant varieties in all these parameters to the level of non-dormant variety. The already better performing nondormant variety enhanced their performance to more heights under the influence of ethrel treatments. Sebastian, (2014) in proso millet and foxtail millet got similar results for seed vigour index parameters.

\section{Interaction effect of varieties $x$ storage periods}

In case of interaction effect of varieties $\mathrm{x}$ storage period, non-dormant GG-7 recorded maximum germination percentage at 7 days after harvest $\left(\mathrm{V}_{1} \mathrm{~S}_{1}\right)$ [75.3\% (90.8\%)]. While minimum germination was recorded in dormant variety GG-11 at 7 days after harvest $\left(\mathrm{V}_{2} \mathrm{~S}_{1}\right)$ [37.5\%) (42.7\%)] and it was at par with GG-20 at 7 days after harvest $\left(\mathrm{V}_{3} \mathrm{~S}_{1}\right)$ [38.1\% (43.5\%)].

GG-7, the non-dormant variety gained maximum speed of germination at 7 days after harvest $\left(\mathrm{V}_{1} \mathrm{~S}_{1}\right)$ [8.9 (78.5)]and it was at par with storage period, 14 days after harvest of same variety $\left(\mathrm{V}_{1} \mathrm{~S}_{2}\right)$ [8.7 (76.0)]. While minimum speed of germination recorded in dormant variety GG-11 at 7 days after harvest $\left(\mathrm{V}_{3} \mathrm{~S}_{1}\right)$ [4.4 (23.4)].

As the storage period advanced a decreasing tendency was followed in case of nondormant variety, GG-7 with highest value marked at 7 days after harvest and lowest result at 28 days after harvest. While in case of dormant varieties, a tendency completely opposite to that of non-dormant variety were observed, with lowest results at 7 days after harvest and maximum recorded at final stage of harvesting (28 days after harvest). Any how the best interaction effect was produced by GG-7 at 7 days after harvest. Gowda and Reddy,(2008); Yadav et al., (2014); Janila et al., (2013); Meena et al., (2017) in groundnut,
Vujakovik et al., (2012) in sunflower got similar results for germination percentage.

GG-7, the non-dormant variety at 7 days after harvest $\left(\mathrm{V}_{1} \mathrm{~S}_{1}\right)$ scored significantly highest seed vigour index-I [31.6 (998.4)] as well as vigour index-II [117.3 (13777.0)]. Minimum seed vigour index-I was scored by GG-11 at 7 days after harvest $\left(\mathrm{V}_{2} \mathrm{~S}_{1}\right)$ [18.5 (340.8)] and it was at par with GG-20 at 7 days after harvest $\left(\mathrm{V}_{3} \mathrm{~S}_{1}\right)$ [18.8 (348.3)] while it was GG20 at 7 days after harvest $\left(\mathrm{V}_{3} \mathrm{~S}_{1}\right)$ [58.8 (4855.0)] scored least for vigour index-II. Interaction effect of GG-7 and storage periods for seed vigour index-I and seed vigour indexII showed significant variation between initial storage period and rest of the storage periods with maximum result from 7 days after harvest and with no significant variation as advancement in storage periods. Interaction effect of GG-20 significantly improved over storage periods. In case of GG-11 both seed vigour index parameters improved with significant variation during initial storage periods (7, 14 and 21 days) which became non-significant later (28 days after harvest). Yadav et al., (2014); Janila et al., (2013); Meena et al., (2017) in groundnut got similar results.

In case of non-dormant varieties, seed quality (viability and vigour) decreases with increase in storage duration. Seed deterioration during storage was due to the damage in cell membrane and other chemical changes in the seed system such as the protein and nucleic acid accumulation. During storage, loss of membrane integrity of all cell organelles accelerates aging. Aging results in reduction in germination percentage and those seeds that do germinate produce weak seedling as well as weakens seedling growth parameters like seedling length and seedling weight.

In case of dormant groundnut varieties, fresh seed dormancy exists, for that they require an 
after ripening period or a resting period for breaking it and to advance into germination phase. This stage of arrested growth, if it falls within storage duration, then seeds can easily escape from seed deterioration and aging. This may be the reason behind promising results from dormant varieties (GG-11 and GG-20) and declining outcomes from nondormant variety (GG-7) with advancement in storage period.

\section{Interaction effect of ethrel concentration $x$ storage periods}

For the interaction effect of ethrel concentrations x storage periods, seeds treated with ethrel @ 75 ppm significantly gained maximum germination percentage at 28 days after harvest $\left(\mathrm{C}_{4} \mathrm{~S}_{4}\right)$ [78.2\% (95.6\%)] and it was at par with the same ethrel concentration at 21 days after harvest $\left(\mathrm{C}_{4} \mathrm{~S}_{3}\right) \quad[77.2 \%$ (94.9\%)]. While minimum germination percentage was recorded in control at 7 days after harvest $\left(\mathrm{C}_{1} \mathrm{~S}_{1}\right)[24.1 \%(28.0 \%)]$.

Seeds treated with ethrel @75 ppm gained maximum speed of germination at 28 days after harvest $\left(\mathrm{C}_{4} \mathrm{~S}_{4}\right)$ [9.0 (81.2)] and it was at par with $\left(\mathrm{C}_{4} \mathrm{~S}_{3}\right)$ [8.8 (77.6)]. Significantly lowest speed of germination was marked in control at 7 days after harvest $\left(\mathrm{C}_{1} \mathrm{~S}_{1}\right)$ [3.4 (23.1)].

Lowest result was recorded in control (water soaking) at 7 days after harvest and as the storage period advanced, outputs also increased but couldn't achieve standard germination percentage even at final stage of storage. This increasing tendency in control with each storage period may be due to the slow release of dormancy during storage. Individually each ethrel concentration promoted enhancement in these parameters with advancement in storage period, where interaction with 7 days after harvest gave lower results, while interaction with final storage period (28 days after harvest) gave higher results.Here the slow release of dormancy by the storage period was accelerated by the ethrel treatments, and increase inethrel concentration more strongly and fastly broke the dormancy. Germination was maintained and many times obtained much above the standard germination prescribed to IMSCS in all storage periods by ethrel@50 ppm,75 ppm and ehtrel @ 25 ppm (except 7 days after harvest). Even though maximum result was given by ethrel @ 75 ppm at 28 days after harvest, nonsignificant variation existed for last two storage periods ( 21 and 28 days after harvest) for ethrel @ 50 and 75 ppm treatments.

Seeds treated with ethrel @ 75 ppm at 28 days after harvest $\left(\mathrm{C}_{4} \mathrm{~S}_{4}\right)$ gained significantly maximum seed vigour index-I [29.6 (875.1)] which was at par with $\left(\mathrm{C}_{4} \mathrm{~S}_{3}\right),\left(\mathrm{C}_{4} \mathrm{~S}_{2}\right)$ and seed vigour index-II[117.8 (13870.0)] which was also at par with $\left(\mathrm{C}_{4} \mathrm{~S}_{3}\right)$. While minimum seed vigour index-I [10.3 (289.6)] and seed vigour index-II [37.4 (40.96)] was marked in control at 7 days after harvest $\left(\mathrm{C}_{1} \mathrm{~S}_{1}\right)$. In all storage periods control recorded minimum interaction effect in seed vigour index-I and ethrel @ 75 ppm marked highest followed by 50 ppm and then $25 \mathrm{ppm}$. In case of seed vigour index-I and seed vigour index-II with increase in ethrel concentration and advancement in storage period significant improvement were produced by interactions. This may be because germination percentage, a parameter that determines vigour index found to follow same pattern of improvement in the same interaction.

If we observe the pattern of variation in case of interaction effect of ethrel concentrations and storage periods, we can see the improvement in parameters with the increase in ethrel concentration (from $25 \mathrm{ppm}$ to 75 ppm) and with the advancement in storage duration (from 7 days to 28 days after harvest). 
Table.1 Three way table of main effect and interaction effect for germination \%

\begin{tabular}{|c|c|c|c|c|c|c|c|c|c|c|c|c|c|c|c|c|c|c|c|c|}
\hline \multicolumn{21}{|c|}{ Character: Germination \% } \\
\hline & \multicolumn{4}{|c|}{$\mathbf{V}_{1}$} & \multicolumn{4}{|c|}{$\mathbf{V}_{2}$} & \multicolumn{4}{|c|}{$\mathbf{V}_{3}$} & \multicolumn{3}{|c|}{ VC } & \multicolumn{4}{|c|}{ CS } & \multirow[b]{2}{*}{$\mathbf{C} \downarrow$} \\
\hline & $\mathbf{S}_{1}$ & $\mathbf{S}_{2}$ & $\mathbf{S}_{\mathbf{3}}$ & $\mathbf{S}_{4}$ & $\mathbf{S}_{1}$ & $\mathbf{S}_{2}$ & $\mathbf{S}_{\mathbf{3}}$ & $\mathbf{S}_{4}$ & $\mathbf{S}_{1}$ & $\mathbf{S}_{2}$ & $\mathbf{S}_{\mathbf{3}}$ & $\mathbf{S}_{4}$ & $V_{1}$ & $\mathbf{V}_{2}$ & $\mathbf{V}_{\mathbf{3}}$ & $\mathbf{S}_{1}$ & S2 & $\mathbf{S}_{\mathbf{3}}$ & $\mathbf{S}_{4}$ & \\
\hline $\mathrm{C}_{1}$ & $\begin{array}{c}66.4 \\
(84.0)\end{array}$ & $\begin{array}{c}65.9 \\
(83.3)\end{array}$ & $\begin{array}{c}62.5 \\
(78.7) \\
\end{array}$ & $\begin{array}{c}60.7 \\
(76.0) \\
\end{array}$ & $\begin{array}{c}2.9 \\
(0.0) \\
\end{array}$ & $\begin{array}{c}21.9 \\
(14.0)\end{array}$ & $\begin{array}{c}48.5 \\
(56.0)\end{array}$ & $\begin{array}{c}55.1 \\
(67.3)\end{array}$ & $\begin{array}{c}2.9 \\
(0.0) \\
\end{array}$ & $\begin{array}{l}16.7 \\
(9.3)\end{array}$ & $\begin{array}{c}28.1 \\
(22.7)\end{array}$ & \begin{tabular}{|c|}
45.0 \\
$(50.0)$
\end{tabular} & \begin{tabular}{|c|}
63.9 \\
$(80.5)$ \\
\end{tabular} & \begin{tabular}{|c|}
32.1 \\
$(34.3)$
\end{tabular} & $\begin{array}{c}23.2 \\
(20.5)\end{array}$ & $\begin{array}{c}24.1 \\
(28.0)\end{array}$ & \begin{tabular}{|c|}
34.8 \\
$(35.6)$
\end{tabular} & $\begin{array}{c}46.3 \\
(52.4)\end{array}$ & $\begin{array}{c}53.6 \\
(64.4)\end{array}$ & $\begin{array}{c}39.7 \\
(45.1)\end{array}$ \\
\hline $\mathrm{C}_{2}$ & $\begin{array}{c}72.0 \\
(89.3)\end{array}$ & $\begin{array}{c}69.2 \\
(87.3)\end{array}$ & $\begin{array}{c}68.6 \\
(86.7)\end{array}$ & $\begin{array}{c}67.5 \\
(85.3) \\
\end{array}$ & $\begin{array}{c}40.0 \\
(41.3) \\
\end{array}$ & $\begin{array}{c}48.1 \\
(55.3)\end{array}$ & $\begin{array}{c}68.6 \\
(86.7)\end{array}$ & $\begin{array}{c}70.8 \\
(88.7) \\
\end{array}$ & $\begin{array}{c}32.8 \\
(29.3) \\
\end{array}$ & $\begin{array}{c}60.2 \\
(75.3)\end{array}$ & $\begin{array}{c}67.5 \\
(85.3) \\
\end{array}$ & \begin{tabular}{|c|}
69.8 \\
$(88.0)$
\end{tabular} & $\begin{array}{c}69.1 \\
(87.2)\end{array}$ & $\begin{array}{c}56.9 \\
(68.0)\end{array}$ & $\begin{array}{c}57.6 \\
(69.5) \\
\end{array}$ & $\begin{array}{c}47.9 \\
(53.3) \\
\end{array}$ & $\begin{array}{c}59.2 \\
(72.7)\end{array}$ & $\begin{array}{c}68.2 \\
(86.2) \\
\end{array}$ & $\begin{array}{c}69.4 \\
(87.3)\end{array}$ & $\begin{array}{c}61.2 \\
(74.9) \\
\end{array}$ \\
\hline$\overline{C_{3}}$ & $\begin{array}{c}75.2 \\
(93.3)\end{array}$ & $\begin{array}{c}71.0 \\
(89.3)\end{array}$ & $\begin{array}{c}72.2 \\
(90.7)\end{array}$ & $\begin{array}{l}71.6 \\
(90)\end{array}$ & $\begin{array}{c}50.0 \\
(58.7)\end{array}$ & $\begin{array}{c}56.0 \\
(68.7)\end{array}$ & $\begin{array}{c}74.3 \\
(92.7)\end{array}$ & $\begin{array}{c}75.1 \\
(93.3)\end{array}$ & $\begin{array}{c}55.2 \\
(67.3)\end{array}$ & $\begin{array}{c}67.1 \\
(84.7)\end{array}$ & $\begin{array}{c}72.2 \\
(90.7)\end{array}$ & $\begin{array}{c}73.7 \\
(92.0)\end{array}$ & $\begin{array}{c}72.5 \\
(90.8)\end{array}$ & $\begin{array}{c}63.8 \\
(78.3)\end{array}$ & $\begin{array}{c}67.0 \\
(83.7)\end{array}$ & $\begin{array}{c}60.1 \\
(73.1)\end{array}$ & $\begin{array}{c}64.7 \\
(80.9)\end{array}$ & $\begin{array}{c}72.9 \\
(91.3)\end{array}$ & $\begin{array}{c}73.4 \\
(91.8) \\
\end{array}$ & $\begin{array}{c}67.8 \\
(84.3)\end{array}$ \\
\hline $\mathrm{C}_{4}$ & $\begin{array}{c}79.6 \\
(96.7)\end{array}$ & $\begin{array}{c}76.0 \\
(94.0) \\
\end{array}$ & $\begin{array}{c}75.2 \\
(93.3)\end{array}$ & \begin{tabular}{|c}
74.3 \\
$(92.7)$ \\
\end{tabular} & $\begin{array}{c}57.2 \\
(70.7) \\
\end{array}$ & $\begin{array}{c}63.9 \\
(80.7)\end{array}$ & $\begin{array}{c}79.6 \\
(96.7)\end{array}$ & $\begin{array}{c}80.7 \\
(97.3) \\
\end{array}$ & $\begin{array}{c}61.6 \\
(77.3) \\
\end{array}$ & $\begin{array}{c}72.3 \\
(90.7)\end{array}$ & $\begin{array}{c}76.7 \\
(94.7)\end{array}$ & $\begin{array}{c}79.6 \\
(96.7) \\
\end{array}$ & $\begin{array}{c}76.3 \\
(94.2)\end{array}$ & $\begin{array}{c}70.4 \\
(86.3)\end{array}$ & $\begin{array}{c}72.6 \\
(89.8) \\
\end{array}$ & $\begin{array}{c}66.2 \\
(81.6) \\
\end{array}$ & $\begin{array}{c}70.7 \\
(88.4) \\
\end{array}$ & \begin{tabular}{|c}
77.2 \\
$(94.9)$ \\
\end{tabular} & $\begin{array}{c}78.2 \\
(95.6) \\
\end{array}$ & \begin{tabular}{|c}
73.1 \\
$(90.1)$ \\
\end{tabular} \\
\hline $\begin{array}{l}\mathbf{V S} \\
\rightarrow\end{array}$ & $\begin{array}{c}75.3 \\
(90.8)\end{array}$ & $\begin{array}{c}72.0 \\
(88.5)\end{array}$ & $\begin{array}{c}69.6 \\
(87.3)\end{array}$ & $\begin{array}{c}68.5 \\
(86.0)\end{array}$ & $\begin{array}{c}37.6 \\
(42.7)\end{array}$ & $\begin{array}{c}47.5 \\
(54.7)\end{array}$ & $\begin{array}{c}67.8 \\
(83.0)\end{array}$ & $\begin{array}{c}70.4 \\
(86.7)\end{array}$ & $\begin{array}{c}38.1 \\
(43.5)\end{array}$ & $\begin{array}{c}54.1 \\
(65.0)\end{array}$ & $\begin{array}{c}61.1 \\
(73.3)\end{array}$ & $\begin{array}{c}67.0 \\
(81.7)\end{array}$ & $\begin{array}{c}71.4 \\
(88.8)\end{array}$ & $\begin{array}{c}55.8 \\
(66.8)\end{array}$ & $\begin{array}{c}55.1 \\
(65.9)\end{array}$ & $\begin{array}{c}49.6 \\
(59.1)\end{array}$ & \begin{tabular}{|c|}
57.3 \\
$(69.4)$
\end{tabular} & $\begin{array}{c}66.2 \\
(81.2)\end{array}$ & $\begin{array}{c}68.7 \\
(84.8)\end{array}$ & $\begin{array}{l}\mathbf{S} \\
\leftarrow\end{array}$ \\
\hline $\begin{array}{c}\text { S.Em } \\
\pm\end{array}$ & V & 0.3 & & $\mathbf{C}$ & 0.41 & & $\mathbf{S}$ & & 0.41 & 146 & & VS & 0.71 & & $\mathrm{VC}$ & $\begin{array}{c}0.718 \\
2\end{array}$ & CS & $\begin{array}{c}0.829 \\
3\end{array}$ & VCS & $\begin{array}{c}1.436 \\
4\end{array} \mid$ \\
\hline CD & $\mathbf{V}$ & 1.00 & 880 & C & 1.16 & & $\mathbf{S}$ & & 1.16 & 540 & & VS & 2.01 & & VC & $\begin{array}{c}2.016 \\
1\end{array}$ & CS & $\begin{array}{c}2.328 \\
0\end{array}$ & VCS & \begin{tabular}{|c|}
4.032 \\
2
\end{tabular} \\
\hline $\mathrm{CV} \%$ & & & & & & & & & & & & & & & & & & & & \\
\hline
\end{tabular}

- Values in parenthesis are original value

- Data has been transformed as per arcsine transformation.

- V: Variety; $\mathrm{V}_{1}$ : GG- 7; $\mathrm{V}_{2}$ : GG-11; $\mathrm{V}_{3}$ : GG-20

- C: Ethrel Concentration; $\mathrm{C}_{1}$ : Control; $\mathrm{C}_{2}$ : Ethrel @ 25 ppm; $\mathrm{C}_{3}$ : Ethrel @ 50 ppm; $\mathrm{C}_{4}$ : Ethrel @ 75 ppm

- $\mathbf{S}_{1}$ : Storage Period; $S_{1}: 7$ days after harvest; $S_{2}: 14$ days after harvest; $S_{3}: 21$ days after harvest; $S_{4}: 28$ days after harvest

- VC: Interaction effect of variety x ethrel concentration; VS: Interaction effect of variety $\mathrm{x}$ storage period; CS: Interaction effect of ethrel concentration $\mathrm{x}$ storage period; VCS: Interaction effect of variety $\mathrm{x}$ ethrel concentration $\mathrm{x}$ storage period 
Table. 2 Three way table of main effect and interaction effect for speed of germination

\begin{tabular}{|c|c|c|c|c|c|c|c|c|c|c|c|c|c|c|c|c|c|c|c|c|}
\hline \multicolumn{21}{|c|}{ Character: Speed of germination } \\
\hline & \multicolumn{4}{|c|}{$\mathbf{V}_{1}$} & \multicolumn{4}{|c|}{$\mathbf{V}_{2}$} & \multicolumn{4}{|c|}{$\mathbf{V}_{3}$} & \multicolumn{3}{|c|}{ VC } & \multicolumn{4}{|c|}{$\mathbf{C S}$} & \\
\hline & $\mathbf{S}_{1}$ & $\mathbf{S}_{2}$ & $\mathbf{S}_{\mathbf{3}}$ & $\mathbf{S}_{4}$ & $\mathbf{S}_{1}$ & $\mathbf{S}_{\mathbf{2}}$ & $\mathbf{S}_{\mathbf{3}}$ & $\mathbf{S}_{4}$ & $\mathbf{S}_{1}$ & $\mathbf{S}_{\mathbf{2}}$ & $\mathbf{S}_{\mathbf{3}}$ & $\mathbf{S}_{4}$ & $\mathbf{V}_{1}$ & $\mathbf{V}_{2}$ & $\mathbf{V}_{3}$ & $\mathbf{S}_{1}$ & $\mathbf{S}_{\mathbf{2}}$ & $\mathbf{S}_{\mathbf{3}}$ & $\mathbf{S}_{4}$ & $\mathbf{C} \downarrow$ \\
\hline $\mathbf{C}_{1}$ & $\begin{array}{c}8.4 \\
(69.2)\end{array}$ & $\begin{array}{c}8.4 \\
(70.6)\end{array}$ & $\begin{array}{c}8.1 \\
(65.0)\end{array}$ & $\begin{array}{c}7.8 \\
(60.5) \\
\end{array}$ & $\begin{array}{c}0.7 \\
(0.0)\end{array}$ & $\begin{array}{c}2.3 \\
(4.9)\end{array}$ & $\begin{array}{c}5.6 \\
(31.5)\end{array}$ & $\begin{array}{c}6.5 \\
(41.8) \\
\end{array}$ & $\begin{array}{c}0.7 \\
(0.0)\end{array}$ & $\begin{array}{c}1.9 \\
(3.3)\end{array}$ & \begin{tabular}{|c|}
2.7 \\
$(6.9)$
\end{tabular} & $\begin{array}{c}4.9 \\
(23.7)\end{array}$ & $\begin{array}{c}8.2 \\
(66.4)\end{array}$ & $\begin{array}{c}3.8 \\
(19.5) \\
\end{array}$ & $\begin{array}{c}2.6 \\
(8.5) \\
\end{array}$ & $\begin{array}{c}3.4 \\
(23.1)\end{array}$ & $\begin{array}{c}4.2 \\
(26.3)\end{array}$ & $\begin{array}{c}5.5 \\
(34.5)\end{array}$ & $\begin{array}{c}6.4 \\
(42,0)\end{array}$ & $\begin{array}{c}4.9 \\
(31.4) \\
\end{array}$ \\
\hline $\mathbf{C}_{2}$ & $\begin{array}{c}8.9 \\
(77.9)\end{array}$ & $\begin{array}{c}8.6 \\
(72.9)\end{array}$ & $\begin{array}{c}8.5 \\
(72.3)\end{array}$ & $\begin{array}{c}8.5 \\
(71.8)\end{array}$ & $\begin{array}{c}4.7 \\
(21.7)\end{array}$ & $\begin{array}{c}5.7 \\
(31.9)\end{array}$ & $\begin{array}{c}7.7 \\
(59.2)\end{array}$ & $\begin{array}{c}8.0 \\
(63.0)\end{array}$ & $\begin{array}{c}4.2 \\
(17.6)\end{array}$ & $\begin{array}{c}6.1 \\
(37.1)\end{array}$ & \begin{tabular}{|c|}
7.6 \\
$(57.9$ \\
)
\end{tabular} & $\begin{array}{c}8.1 \\
(64.4)\end{array}$ & $\begin{array}{c}8.6 \\
(73.7)\end{array}$ & $\begin{array}{c}6.5 \\
(44.0)\end{array}$ & $\begin{array}{c}6.5 \\
(44.3)\end{array}$ & $\begin{array}{c}5.9 \\
(39.1)\end{array}$ & $\begin{array}{c}6.8 \\
(47.3)\end{array}$ & $\begin{array}{c}8.0 \\
(63.2)\end{array}$ & $\begin{array}{c}8.2 \\
(66.4)\end{array}$ & $\begin{array}{c}7.2 \\
(54.0)\end{array}$ \\
\hline $\mathbf{C}_{3}$ & $\begin{array}{c}9.1 \\
(82.2)\end{array}$ & $\begin{array}{c}8.8 \\
(77.5) \\
\end{array}$ & $\begin{array}{c}8.8 \\
(77.4) \\
\end{array}$ & $\begin{array}{c}8.7 \\
(76.0) \\
\end{array}$ & $\begin{array}{c}5.7 \\
(31.6) \\
\end{array}$ & $\begin{array}{c}6.3 \\
(39.6) \\
\end{array}$ & $\begin{array}{c}8.3 \\
(67.9) \\
\end{array}$ & $\begin{array}{c}8.8 \\
(76.2) \\
\end{array}$ & $\begin{array}{c}6.3 \\
(39.6) \\
\end{array}$ & $\begin{array}{c}6.9 \\
(47.4) \\
\end{array}$ & $\begin{array}{c}8.2 \\
(67) \\
\end{array}$ & $\begin{array}{c}8.6 \\
(74.1)\end{array}$ & $\begin{array}{c}8.9 \\
(78.3) \\
\end{array}$ & $\begin{array}{c}7.3 \\
(53.8) \\
\end{array}$ & $\begin{array}{c}7.5 \\
(57.0) \\
\end{array}$ & $\begin{array}{c}7.0 \\
(51.1) \\
\end{array}$ & $\begin{array}{c}7.4 \\
(54.8) \\
\end{array}$ & $\begin{array}{c}8.4 \\
(70.8) \\
\end{array}$ & $\begin{array}{c}8.7 \\
(75.4) \\
\end{array}$ & $\begin{array}{c}7.9 \\
(63.0) \\
\end{array}$ \\
\hline $\mathbf{C}_{4}$ & $\begin{array}{c}9.2 \\
(84.8)\end{array}$ & $\begin{array}{c}9.1 \\
(82.9)\end{array}$ & $\begin{array}{c}9.0 \\
(81.1)\end{array}$ & $\begin{array}{c}9.0 \\
(80.6)\end{array}$ & $\begin{array}{c}6.4 \\
(40.1)\end{array}$ & $\begin{array}{c}7.0 \\
(48.9)\end{array}$ & $\begin{array}{c}8.8 \\
(76.5)\end{array}$ & $\left(\begin{array}{c}9.0 \\
(81.4)\end{array}\right.$ & $\begin{array}{c}7.0 \\
(49.0)\end{array}$ & $\begin{array}{c}7.3 \\
(52.7)\end{array}$ & \begin{tabular}{|c|}
8.7 \\
$(75.2$ \\
) \\
\end{tabular} & $\begin{array}{c}9.1 \\
(81.7)\end{array}$ & $\begin{array}{c}9.1 \\
(82.3)\end{array}$ & $\left(\begin{array}{c}7.9 \\
(61.7)\end{array}\right.$ & $\begin{array}{c}8.0 \\
(64.6)\end{array}$ & $\left(\begin{array}{c}7.6 \\
(58.0)\end{array}\right.$ & $\begin{array}{c}7.8 \\
(61.5)\end{array}$ & $\begin{array}{c}8.8 \\
(77.6)\end{array}$ & $\mid \begin{array}{c}9.0 \\
(81.2)\end{array}$ & $\begin{array}{c}8.3 \\
(69.6)\end{array}$ \\
\hline $\begin{array}{l}\text { VS } \\
\rightarrow\end{array}$ & $\begin{array}{c}8.9 \\
(78.5)\end{array}$ & $\begin{array}{c}8.7 \\
(76.0)\end{array}$ & $\begin{array}{c}8.6 \\
(74.0)\end{array}$ & $\begin{array}{c}8.5 \\
(72.2)\end{array}$ & $\begin{array}{c}4.4 \\
(23.4)\end{array}$ & $\begin{array}{c}5.3 \\
(31.3)\end{array}$ & $\begin{array}{c}7.6 \\
(58.8)\end{array}$ & $\begin{array}{c}8.1 \\
(65.6)\end{array}$ & $\begin{array}{c}4.6 \\
(26.5)\end{array}$ & $\begin{array}{c}5.6 \\
(35.1)\end{array}$ & \begin{tabular}{|c|}
6.8 \\
$(51.7$ \\
)
\end{tabular} & $\begin{array}{c}7.7 \\
(61.0)\end{array}$ & $\begin{array}{c}8.7 \\
(75.9)\end{array}$ & $\left(\begin{array}{c}6.4 \\
(44.8)\end{array}\right.$ & $\begin{array}{c}6.2 \\
(43.6)\end{array}$ & $\left(\begin{array}{c}5.9 \\
(42.8)\end{array}\right.$ & $\begin{array}{c}6.6 \\
(47.5)\end{array}$ & $\left(\begin{array}{c}7.7 \\
(61.5)\end{array}\right.$ & $\begin{array}{c}8.1 \\
(66.3)\end{array}$ & $\begin{array}{l}\mathbf{S} \\
\leftarrow\end{array}$ \\
\hline S.Em \pm & $\mathbf{V}$ & 0.0 & 241 & $\mathbf{C}$ & 0.02 & 278 & $\mathbf{S}$ & & 0.02 & & & VS & 0.0 & 482 & $\mathbf{V C}$ & \begin{tabular}{|c}
0.048 \\
2
\end{tabular} & CS & $\begin{array}{c}0.055 \\
7\end{array}$ & VCS & $\begin{array}{c}0.096 \\
4\end{array}$ \\
\hline CD & $\mathbf{V}$ & 0.06 & & $\mathbf{C}$ & $0.0^{-}$ & 782 & $\mathbf{S}$ & & 0.07 & 782 & & VS & 0.13 & 354 & VC & \begin{tabular}{|c}
0.135 \\
4
\end{tabular} & CS & $\begin{array}{c}0.156 \\
3\end{array}$ & VCS & $\begin{array}{c}0.270 \\
7\end{array}$ \\
\hline CV\% & & & & & & & & & & 3650 & & & & & & & & & & \\
\hline
\end{tabular}

- Values in parenthesis are original value

- Data has been transformed as per arcsine transformation.

- V: Variety; $\mathbf{V}_{\mathbf{1}}$ : GG- 7; $\mathbf{V}_{2}$ : GG-11; $\mathbf{V}_{3}$ : GG-20,

- C: Ethrel Concentration; $\mathbf{C}_{1}$ : Control; $\mathbf{C}_{2}$ : Ethrel @ 25ppm; $\mathbf{C}_{3}$ : Ethrel @ 50ppm; $\mathbf{C}_{4}$ : Ethrel @ 75ppm

- S: Storage Period; $\mathbf{S}_{\mathbf{1}}: 7$ days after harvest; $\mathbf{S}_{2}: 14$ days after harvest; $\mathbf{S}_{\mathbf{3}}: 21$ days after harvest; $\mathbf{S}_{\mathbf{4}}: 28$ days after harvest

- VC: Interaction effect of variety $x$ ethrel concentration; VS: Interaction effect of variety $x$ storage period; $\mathbf{C S}$ : Interaction effect of ethrel concentration $\mathrm{x}$ storage period; VCS: Interaction effect of variety $\mathrm{x}$ ethrel concentration $\mathrm{x}$ storage period 
Table.3 Three way table of main effect and interaction effect for seed vigour index-I

\begin{tabular}{|c|c|c|c|c|c|c|c|c|c|c|c|c|c|c|c|c|c|c|c|c|}
\hline \multicolumn{21}{|c|}{ Character: Seed vigour index-I } \\
\hline & \multicolumn{4}{|c|}{$\mathbf{V}_{1}$} & \multicolumn{4}{|c|}{$\mathbf{V}_{2}$} & \multicolumn{4}{|c|}{$\mathbf{V}_{3}$} & \multicolumn{3}{|c|}{ VC } & \multicolumn{4}{|c|}{ CS } & \multirow[b]{2}{*}{$\mathbf{C} \downarrow$} \\
\hline & $\mathbf{S}_{1}$ & $\mathbf{S}_{2}$ & $\mathbf{S}_{3}$ & $\mathbf{S}_{4}$ & $\mathbf{S}_{1}$ & $\mathbf{S}_{2}$ & $\mathbf{S}_{3}$ & $\mathbf{S}_{4}$ & $\mathbf{S}_{1}$ & $\mathbf{S}_{2}$ & $\mathbf{S}_{3}$ & $\mathbf{S}_{4}$ & $\overline{V_{1}}$ & $\overline{V_{2}}$ & $\mathbf{V}_{3}$ & $\mathbf{S}_{1}$ & $\mathbf{S}_{2}$ & $\mathbf{S}_{3}$ & $\mathbf{S}_{4}$ & \\
\hline $\mathbf{C}_{1}$ & $\begin{array}{c}29.5 \\
(868.9)\end{array}$ & $\begin{array}{c}28.8 \\
(831)\end{array}$ & $\begin{array}{c}26.9 \\
(724.7)\end{array}$ & $\begin{array}{c}26.1 \\
(680.2)\end{array}$ & $\begin{array}{c}0.7 \\
(0.0)\end{array}$ & $\begin{array}{c}9.7 \\
(95.4)\end{array}$ & $\begin{array}{c}19.9 \\
(395.4)\end{array}$ & $\begin{array}{c}21.9 \\
(479)\end{array}$ & $\begin{array}{c}0.7 \\
(0.0)\end{array}$ & $\begin{array}{c}7.6 \\
(66.2)\end{array}$ & $\begin{array}{c}12.5 \\
(162.2)\end{array}$ & $\begin{array}{c}19.1 \\
(364.1)\end{array}$ & $\begin{array}{c}27.8 \\
(776.2)\end{array}$ & $\begin{array}{c}13.1 \\
(242.4)\end{array}$ & $\begin{array}{c}10.0 \\
(148.1)\end{array}$ & $\begin{array}{c}10.3 \\
(289.6)\end{array}$ & $\begin{array}{c}15.4 \\
(330.9)\end{array}$ & $\begin{array}{c}19.8 \\
(427.4)\end{array}$ & $\begin{array}{c}22.4 \\
(507.8)\end{array}$ & $\begin{array}{c}17.0 \\
(388.9)\end{array}$ \\
\hline $\mathbf{C}_{2}$ & $\begin{array}{c}31.2 \\
(973.6)\end{array}$ & $\begin{array}{c}30.5 \\
(932.6)\end{array}$ & $\begin{array}{c}29.0 \\
(843.3)\end{array}$ & $\begin{array}{c}28.7 \\
(820.9)\end{array}$ & $\begin{array}{c}17.4 \\
(301.2)\end{array}$ & $\begin{array}{c}20.3 \\
(411.1)\end{array}$ & $\begin{array}{c}26.0 \\
(676.4)\end{array}$ & $\begin{array}{c}26.4 \\
(699.3)\end{array}$ & $\begin{array}{c}14.8 \\
(219.3)\end{array}$ & $\begin{array}{c}24.4 \\
(592.7)\end{array}$ & $\begin{array}{c}26.3 \\
(688.9)\end{array}$ & $\begin{array}{c}26.8 \\
(718.5)\end{array}$ & $\begin{array}{c}29.9 \\
(892.6)\end{array}$ & $\begin{array}{c}22.5 \\
(522.0)\end{array}$ & $\begin{array}{c}23.1 \\
(554.9)\end{array}$ & $\begin{array}{c}21.1 \\
(498.0)\end{array}$ & $\begin{array}{c}25.1 \\
(645.4)\end{array}$ & $\begin{array}{c}27.1 \\
(736.2)\end{array}$ & $\begin{array}{c}27.3 \\
(746.2)\end{array}$ & $\begin{array}{c}25.2 \\
(656.5)\end{array}$ \\
\hline $\mathbf{C}_{3}$ & $\begin{array}{c}32.4 \\
(1049.1)\end{array}$ & $\begin{array}{c}31.2 \\
(974.3)\end{array}$ & $\begin{array}{c}30.2 \\
(912.1)\end{array}$ & $\begin{array}{c}29.8 \\
(890.1)\end{array}$ & $\begin{array}{c}21.7 \\
(468.6)\end{array}$ & $\begin{array}{c}23.6 \\
(557.5)\end{array}$ & $\begin{array}{c}27.8 \\
(771.2)\end{array}$ & \begin{tabular}{|c|}
28.0 \\
$(783.1)$
\end{tabular} & $\begin{array}{c}23.1 \\
(534)\end{array}$ & $\begin{array}{c}26.4 \\
(698.9)\end{array}$ & $\begin{array}{c}27.4 \\
(752.2)\end{array}$ & \begin{tabular}{|c|}
27.8 \\
$(772.1)$
\end{tabular} & $\begin{array}{c}30.9 \\
(956.4)\end{array}$ & $\begin{array}{c}25.3 \\
(645.1)\end{array}$ & $\begin{array}{c}26.2 \\
(689.3)\end{array}$ & $\begin{array}{c}25.7 \\
(683.9)\end{array}$ & $\begin{array}{c}27.1 \\
(743.6)\end{array}$ & $\begin{array}{c}28.5 \\
(811.9)\end{array}$ & $\begin{array}{c}28.5 \\
(815.1)\end{array}$ & $\begin{array}{c}27.5 \\
(763.6)\end{array}$ \\
\hline $\mathbf{C}_{4}$ & $\begin{array}{c}33.2 \\
(1102.0)\end{array}$ & $\begin{array}{c}32.4 \\
(1046.3)\end{array}$ & $\begin{array}{c}31.1 \\
(965.7)\end{array}$ & $\begin{array}{c}30.8 \\
(945.5)\end{array}$ & $\begin{array}{c}24.4 \\
(593.4)\end{array}$ & $\begin{array}{c}26.2 \\
(685.7)\end{array}$ & $\begin{array}{c}28.8 \\
(831.1)\end{array}$ & $\begin{array}{c}29.0 \\
(838.4)\end{array}$ & $\begin{array}{c}25.3 \\
(639.8)\end{array}$ & $\begin{array}{c}27.7 \\
(768.2)\end{array}$ & $\begin{array}{c}28.6 \\
(820.1)\end{array}$ & $\begin{array}{c}29.0 \\
(841.3)\end{array}$ & $\begin{array}{c}31.8 \\
(1014.9)\end{array}$ & $\begin{array}{c}27.1 \\
(737.1)\end{array}$ & $\begin{array}{c}27.7 \\
(767.4)\end{array}$ & $\begin{array}{c}27.6 \\
(778.4)\end{array}$ & $\begin{array}{c}28.8 \\
(833.4)\end{array}$ & $\begin{array}{c}29.5 \\
(872.3)\end{array}$ & $\begin{array}{c}29.6 \\
(875.1)\end{array}$ & $\begin{array}{c}28.9 \\
(839.8)\end{array}$ \\
\hline $\begin{array}{l}\text { VS } \\
\rightarrow\end{array}$ & $\begin{array}{c}31.6 \\
(998.4)\end{array}$ & $\begin{array}{c}30.7 \\
(946.0)\end{array}$ & $\begin{array}{c}29.3 \\
(861.4)\end{array}$ & $\begin{array}{c}28.8 \\
(834.2)\end{array}$ & $\begin{array}{c}18.5 \\
(340.8)\end{array}$ & $\begin{array}{c}20.0 \\
(437.4)\end{array}$ & $\begin{array}{c}25.6 \\
(668.5)\end{array}$ & \begin{tabular}{|c|}
26.3 \\
$(699.9)$ \\
\end{tabular} & $\begin{array}{c}18.8 \\
(348.3)\end{array}$ & $\begin{array}{c}21.5 \\
(531.5)\end{array}$ & $\begin{array}{c}23.7 \\
(605.9) \\
\end{array}$ & \begin{tabular}{|c|}
25.7 \\
$(674.0)$
\end{tabular} & $\begin{array}{c}30.1 \\
(910.0)\end{array}$ & $\begin{array}{c}22.0 \\
(536.7)\end{array}$ & $\begin{array}{c}21.7 \\
(539.9)\end{array}$ & $\begin{array}{c}21.2 \\
(562.5)\end{array}$ & \begin{tabular}{|c|}
24.1 \\
$(638.3)$ \\
\end{tabular} & $\begin{array}{c}26.2 \\
(711.9)\end{array}$ & $\begin{array}{c}26.9 \\
(736.0)\end{array}$ & $\begin{array}{l}\mathbf{S} \\
\leftarrow\end{array}$ \\
\hline $\begin{array}{c}\text { S.Em } \\
\pm\end{array}$ & $\mathbf{V}$ & 0.12 & & $\mathbf{C}$ & 0.1 & 398 & $\mathbf{S}$ & & & & & VS & 0.2 & & VC & 0.2422 & CS & 0.2797 & VCS & 0.4844 \\
\hline CD & $\mathbf{V}$ & 0.33 & & $\mathbf{C}$ & 0.3 & 925 & $\mathbf{S}$ & & 0.3 & 925 & & VS & 0.67 & & VC & 0.6799 & $\mathrm{CS}$ & 0.7851 & VCS & 1.3598 \\
\hline $\mathrm{CV} \%$ & & & & & & & & & & & 4092 & & & & & & & & & \\
\hline
\end{tabular}

- Values in parenthesis are original value

- Data has been transformed as per square-root transformation.

- V: Variety; $\mathbf{V}_{1}$ : GG- $7 ; \mathbf{V}_{2}:$ GG-11; $\mathbf{V}_{3}$ : GG-20,

- C: Ethrel Concentration; $\mathbf{C}_{1}$ : Control; $\mathbf{C}_{2}$ : Ethrel @25ppm; $\mathbf{C}_{3}$ : Ethrel @ 50ppm; $\mathbf{C}_{4}$ : Ethrel @ 75ppm

- S: Storage Period; $\mathbf{S}_{1}: 7$ days after Harvest; $\mathbf{S}_{2}: 14$ days after Harvest; $\mathbf{S}_{\mathbf{3}}: 21$ days after Harvest; $\mathbf{S}_{\mathbf{4}}: 28$ days after Harvest

- VC: Interaction effect of variety $\mathrm{x}$ ethrel concentration; VS: Interaction effect of variety $\mathrm{x}$ storage period; CS: Interaction effect of ethrel concentration $\mathrm{x}$ storage period; VCS: Interaction effect of variety $\mathrm{x}$ ethrel concentration $\mathrm{x}$ storage period 
Table.4 Three way table of main effect and interaction effect for seed vigour index (mass)

\begin{tabular}{|c|c|c|c|c|c|c|c|c|c|c|c|c|c|c|c|c|c|c|c|c|}
\hline \multicolumn{21}{|c|}{ Character: Seed vigour index-II(mass) } \\
\hline & \multicolumn{4}{|c|}{$\mathbf{V}_{1}$} & \multicolumn{4}{|c|}{$\mathbf{V}_{2}$} & \multicolumn{4}{|c|}{$\mathbf{V}_{3}$} & \multicolumn{3}{|c|}{$\mathbf{V C}$} & \multicolumn{4}{|c|}{$\mathbf{C S}$} & \\
\hline & $\mathbf{S}_{1}$ & $\mathbf{S}_{2}$ & $\mathbf{S}_{3}$ & $\mathbf{S}_{4}$ & $\mathbf{S}_{1}$ & $\mathbf{S}_{2}$ & $\mathbf{S}_{3}$ & $\mathbf{S}_{4}$ & $\mathbf{S}_{1}$ & $\mathbf{S}_{2}$ & $\mathbf{S}_{3}$ & $\mathbf{S}_{4}$ & $\mathbf{V}_{1}$ & $V_{2}$ & $\mathbf{V}_{3}$ & $\mathbf{S}_{1}$ & $\mathbf{S}_{2}$ & $\mathbf{S}_{3}$ & $\mathbf{S}_{4}$ & $\mathbf{C} \downarrow$ \\
\hline $\mathbf{C}_{1}$ & $\begin{array}{c}110.9 \\
(12288)\end{array}$ & $\begin{array}{c}109.2 \\
(11921)\end{array}$ & $\begin{array}{c}105.8 \\
(11195)\end{array}$ & $\begin{array}{c}103.6 \\
(10743)\end{array}$ & $\begin{array}{c}0.7 \\
(0.0)\end{array}$ & $\begin{array}{c}38.5 \\
(1497)\end{array}$ & $\begin{array}{c}77.3 \\
(5984)\end{array}$ & $\begin{array}{c}85(722 \\
6.7)\end{array}$ & $\begin{array}{c}0.7 \\
(0.0)\end{array}$ & $\begin{array}{c}29.6 \\
(1007)\end{array}$ & $\begin{array}{c}50.1 \\
(2588)\end{array}$ & $\begin{array}{c}71.2 \\
(5077)\end{array}$ & $\begin{array}{c}107.4 \\
(11537)\end{array}$ & $\begin{array}{c}50.4 \\
(3677)\end{array}$ & $\begin{array}{c}37.9 \\
(2168)\end{array}$ & $\begin{array}{c}37.4 \\
(4096)\end{array}$ & $\begin{array}{c}59.1 \\
(4808)\end{array}$ & $\begin{array}{c}77.7 \\
(6589)\end{array}$ & $\begin{array}{c}86.6 \\
(7682)\end{array}$ & $\begin{array}{c}65.2 \\
(5794)\end{array}$ \\
\hline $\mathbf{C}_{2}$ & $\begin{array}{c}115.6 \\
(13372)\end{array}$ & $\begin{array}{c}112.7 \\
(12693)\end{array}$ & $\begin{array}{c}112.5 \\
(12655)\end{array}$ & $\begin{array}{c}111.4 \\
(12400)\end{array}$ & $\begin{array}{c}68.1 \\
(4643)\end{array}$ & $\begin{array}{c}79.0 \\
(6250)\end{array}$ & $\begin{array}{c}102.7 \\
(10540)\end{array}$ & $\begin{array}{c}104.4 \\
(10907)\end{array}$ & $\begin{array}{c}52.2 \\
(2734)\end{array}$ & $\begin{array}{c}95.6 \\
(9141)\end{array}$ & $\begin{array}{c}102.3 \\
(10469)\end{array}$ & $\begin{array}{c}105.0 \\
(11033)\end{array}$ & $\begin{array}{c}113.0 \\
(12780)\end{array}$ & $\begin{array}{c}88.6 \\
(8085)\end{array}$ & $\begin{array}{c}88.8 \\
(8345)\end{array}$ & $\begin{array}{c}78.7 \\
(6916)\end{array}$ & $\begin{array}{c}95.8 \\
(9361)\end{array}$ & $\begin{array}{c}105.8 \\
(11221)\end{array}$ & $\begin{array}{c}106.9 \\
(11447)\end{array}$ & $\begin{array}{c}96.8 \\
(9736)\end{array}$ \\
\hline $\mathbf{C}_{3}$ & $\begin{array}{c}120.4 \\
(14497)\end{array}$ & $\begin{array}{c}115.0 \\
(13221)\end{array}$ & $\begin{array}{c}116.1 \\
(13479)\end{array}$ & $\begin{array}{c}115.3 \\
(13290)\end{array}$ & $\begin{array}{c}88.0 \\
(7741)\end{array}$ & $\begin{array}{c}95.0 \\
(9017)\end{array}$ & $\begin{array}{c}112.5 \\
(12662)\end{array}$ & $\begin{array}{c}112.9 \\
(12755)\end{array}$ & \begin{tabular}{|c|}
85.3 \\
$(7283)$
\end{tabular} & $\begin{array}{c}104.1 \\
(10843)\end{array}$ & $\begin{array}{c}110.2 \\
(12148)\end{array}$ & $\begin{array}{c}111.6 \\
(12450)\end{array}$ & $\begin{array}{c}116.7 \\
(13622)\end{array}$ & $\begin{array}{c}102.1 \\
(10544)\end{array}$ & $\begin{array}{c}102.8 \\
(10681)\end{array}$ & $\begin{array}{c}97.9 \\
(9841)\end{array}$ & $\begin{array}{c}104.7 \\
(11027)\end{array}$ & $\begin{array}{c}112.9 \\
(12763)\end{array}$ & $\begin{array}{c}113.3 \\
(12832)\end{array}$ & $\begin{array}{c}107.2 \\
(11616)\end{array}$ \\
\hline $\mathbf{C}_{4}$ & $\begin{array}{c}122.3 \\
(14949)\end{array}$ & $\begin{array}{c}118.9 \\
(14132)\end{array}$ & $\begin{array}{c}118.8 \\
(14123)\end{array}$ & $\begin{array}{c}118.2 \\
(13963)\end{array}$ & $\begin{array}{c}99.9 \\
(9994)\end{array}$ & $\begin{array}{c}107.4 \\
(11535)\end{array}$ & $\begin{array}{c}118.3 \\
(13986)\end{array}$ & $\begin{array}{c}118.7 \\
(14082)\end{array}$ & $\begin{array}{c}96.9 \\
(9401)\end{array}$ & $\begin{array}{c}112.1 \\
(12565)\end{array}$ & $\begin{array}{c}115.3 \\
(13289)\end{array}$ & $\begin{array}{c}116.4 \\
(13563)\end{array}$ & $\begin{array}{c}119.5 \\
(14292)\end{array}$ & $\begin{array}{c}111.1 \\
(12399)\end{array}$ & $\begin{array}{c}110.2 \\
(12205)\end{array}$ & $\begin{array}{c}106.4 \\
(11448)\end{array}$ & $\begin{array}{c}112.8 \\
(12744)\end{array}$ & $\begin{array}{c}117.4 \\
(13799)\end{array}$ & $\begin{array}{c}117.8 \\
(13870)\end{array}$ & $\begin{array}{c}113.6 \\
(12965)\end{array}$ \\
\hline $\begin{array}{l}\text { VS } \\
\rightarrow\end{array}$ & $\begin{array}{c}117.3 \\
(13777)\end{array}$ & $\begin{array}{c}113.9 \\
(12992)\end{array}$ & $\begin{array}{c}113.3 \\
(12863)\end{array}$ & $\begin{array}{c}112.1 \\
(12599)\end{array}$ & $\begin{array}{c}64.2 \\
(5594) \\
\end{array}$ & $\begin{array}{c}80.0 \\
(7075)\end{array}$ & $\begin{array}{c}102.7 \\
(10793)\end{array}$ & $\begin{array}{c}105.3 \\
(11243) \\
\end{array}$ & $\begin{array}{c}58.8 \\
(4855)\end{array}$ & $\begin{array}{c}85.4 \\
(8389)\end{array}$ & $\begin{array}{c}94.5 \\
(9624)\end{array}$ & $\begin{array}{c}101.1 \\
(10531)\end{array}$ & $\begin{array}{c}114.2 \\
(13058)\end{array}$ & $\begin{array}{c}88.0 \\
(8676)\end{array}$ & $\begin{array}{c}84.9 \\
(8350)\end{array}$ & $\begin{array}{c}80.1 \\
(8075)\end{array}$ & $\begin{array}{c}93.1 \\
(9485)\end{array}$ & $\begin{array}{c}103.5 \\
(11093) \\
\end{array}$ & $\begin{array}{c}106.1 \\
(11458) \\
\end{array}$ & $\begin{array}{l}\mathbf{S} \\
\leftarrow\end{array}$ \\
\hline S.Emt & $\mathbf{V}$ & 0.4 & 4680 & $\mathrm{C}$ & 0.5 & 404 & $\mathbf{S}$ & & & 5404 & & VS & & 9360 & VC & 0.9360 & $\mathrm{CS}$ & 1.0808 & VCS & 1.8719 \\
\hline CD & V & 1.3 & 3137 & C & 1.5 & 170 & $\mathbf{S}$ & & 1.5 & 5170 & & VS & 2.6 & 6275 & VC & 2.6275 & CS & 3.0339 & VCS & 5.2529 \\
\hline CV\% & & & & & & & & & & & 880 & & & & & & & & & \\
\hline
\end{tabular}

- Values in parenthesis are original value

- Data has been transformed as per square-root transformation.

- V: Variety; $\mathbf{V}_{1}$ : GG- 7; $\mathbf{V}_{2}$ : GG-11; $\mathbf{V}_{3}$ : GG-20.

- $\mathbf{C}$ : Ethrel Concentration; $\mathbf{C}_{1}$ : Control; $\mathbf{C}_{2}$ : Ethrel @25ppm; $\mathbf{C}_{3}$ : Ethrel @ 50ppm; $\mathbf{C}_{4}$ : Ethrel @75ppm

- $\mathbf{S}$ : Storage Period; $\mathbf{S}_{\mathbf{1}}$ : 7 days after harvest; $\mathbf{S}_{\mathbf{2}}$ : 14 days after harvest; $\mathbf{S}_{\mathbf{3}}: 21$ days after harvest; $\mathbf{S}_{\mathbf{4}}$ : 28 days after harvest

- VC: Interaction effect of variety x ethrel concentration; VS: Interaction effect of variety x storage period; CS: Interaction effect of ethrelconcentration x storage period; VCS: Interaction effect of variety $\mathrm{x}$ ethrel concentration $\mathrm{x}$ storage period 
In case of dormant groundnut varieties, fresh seed dormancy exists, for that they require an after ripening period or a resting period for breaking it and to advance into germination phase. This stage of arrested growth, if it falls within storage duration, then there will be slow release of dormancy over the storage period. When this storage period combines with ethrel concentration, dormancy release was accelerated because ethrel (an ethylene compound) can effectively break seed dormancy and can also reduce the time required for radicle emergence in nondormant seeds.

\section{Interaction effect of verities $x$ ethrel concentrations $\mathrm{x}$ storage periods}

In case of the interaction effect of varieties $x$ ethrel concentration $\mathrm{x}$ storage period, seeds treated with ethrel @ 75 ppm gained maximum germination percentage at 28 days after harvest in case of dormant variety GG$11\left(\mathrm{~V}_{2} \mathrm{C}_{4} \mathrm{~S}_{4}\right)$ [80.7\% (97.3\%) which was at par with other treatments; $\left(\mathrm{V}_{1} \mathrm{C}_{4} \mathrm{~S}_{1}\right)$, $\left(\mathrm{V}_{2} \mathrm{C}_{4} \mathrm{~S}_{3}\right)$, $\left(\mathrm{V}_{3} \mathrm{C}_{4} \mathrm{~S}_{3}\right)$ and $\left(\mathrm{V}_{3} \mathrm{C}_{4} \mathrm{~S}_{4}\right)$. While minimum germination per cent was recorded in control at 7 days after harvest [2.9\% $(0.0 \%)]$ for both dormant varieties $\left(\mathrm{V}_{2} \mathrm{C}_{1} \mathrm{~S}_{1}\right.$ and $\left(\mathrm{V}_{3} \mathrm{C}_{1} \mathrm{~S}_{1}\right)$

When comes to the speed of germination, GG-7 seeds treated with ethrel @ 75 ppm at 7 days after harvest $\left(\mathrm{V}_{1} \mathrm{C}_{4} \mathrm{~S}_{1}\right)$ gained maximum result [9.2 (84.8)] and it was at par with many other treatments; $\left(\mathrm{V}_{1} \mathrm{C}_{4} \mathrm{~S}_{2}\right), \quad\left(\mathrm{V}_{1} \mathrm{C}_{4} \mathrm{~S}_{3}\right)$, $\left(\mathrm{V}_{1} \mathrm{C}_{4} \mathrm{~S}_{4}\right),\left(\mathrm{V}_{1} \mathrm{C}_{3} \mathrm{~S}_{1}\right),\left(\mathrm{V}_{2} \mathrm{C}_{4} \mathrm{~S}_{4}\right)$ and $\left(\mathrm{V}_{3} \mathrm{C}_{4} \mathrm{~S}_{4}\right)$. While minimum speed of germination was recorded in control at 7 days after harvest [0.7 (0.0)] for both dormant varieties; GG-11 $\left(\mathrm{V}_{2} \mathrm{C}_{1} \mathrm{~S}_{1}\right)$ and GG-20 $\left(\mathrm{V}_{3} \mathrm{C}_{1} \mathrm{~S}_{1}\right)$.

Seeds of non-dormant varieties GG-7 treated with ethrel @ 75 ppm 7 days after harvest $\left(\mathrm{V}_{1} \mathrm{C}_{4} \mathrm{~S}_{1}\right)$ gained maximum seed vigour indexI[33.2 (1102.0)] which was at par with
$\left(\mathrm{V}_{1} \mathrm{C}_{4} \mathrm{~S}_{2}\right),\left(\mathrm{V}_{1} \mathrm{C}_{3} \mathrm{~S}_{1}\right)$ and seed vigour index-II [122.3 (14949.0)] which was also at par with other treatments; $\left(\mathrm{V}_{1} \mathrm{C}_{4} \mathrm{~S}_{2}\right), \quad\left(\mathrm{V}_{1} \mathrm{C}_{4} \mathrm{~S}_{3}\right)$, $\left(\mathrm{V}_{1} \mathrm{C}_{4} \mathrm{~S}_{4}\right), \quad\left(\mathrm{V}_{1} \mathrm{C}_{3} \mathrm{~S}_{1}\right)$ and $\left(\mathrm{V}_{2} \mathrm{C}_{4} \mathrm{~S}_{4}\right)$. Significantly lowest result for seed vigour index-I as well as vigour index-II was recorded in control at 7 days after harvest [0.7 (0.0)] for both dormant varieties; GG-11 $\left(\mathrm{V}_{2} \mathrm{C}_{1} \mathrm{~S}_{1}\right)$ and GG-20 $\left(\mathrm{V}_{3} \mathrm{C}_{1} \mathrm{~S}_{1}\right)$. Here in case of all interactions higher seed vigour index were promoted by ethrel @ 75 ppm and least values for seed vigour index were recorded in control for all varieties irrespective of storage periods.

In case dormant varieties, availability of resting or after ripening period during storage aids in slow release of dormancy without deterioration of seed quality and exogenous application of ethrel that counteract the seed germination inhibitors promoted improvement in all parameters over the advancement in storage period and increase in ethrel concentration. For non-dormant variety, advances in storage period resulted in declining of these parameters due to deterioration of seed quality due to aging but ethrel treatments effectively rectified these storage problems.

In conclusion, ethrel treatments and storage can be used as a tool for breaking the fresh seed dormancy present in groundnut seeds. Pre-soaking of seeds in ethrel @ 75 ppm and a storage period of 28 days after harvest can effectively broke the seed dormancy present in GG-11 and GG-20 and can also effectively promote improvement of seed quality parameters; germination (\%), speed of germination, seed vigour index-I and seed vigour index-II to the level of performance of non-dormant variety. Increase in ethrel concentration and advancement in storage period improved all the seed quality parameters for dormant varieties; GG-11 and GG-20. Whereas advancement in storage 
period deteriorated non-dormant variety GG7 , but ethrel treatment resulted in betterment of all seed quality parameters and especially helped in maintaining seed quality during storage by preventing deterioration.

\section{Acknowledgment}

I express my heartfelt and sincere thanks to my honorable advisor Dr. Rajiv Kumar Assistant professor, Department of Genetics and Plant breeding, College of Agriculture, Junagadh Agricultural University, Junagadh for his illuminating guidance and Seed Science and Technology department, J. A. U, Junagadh for providing necessary facilities for conducting the research work and for necessary help and co-operation to me during the period of study.

\section{References}

Adebisi, M. A. and Ajala, M. O. (2007). Effect of genotypes and seed production environments on seed quality of sesame (Sesamum indicum). Tanzania J. Agric. Sci., 2: 87-102.

Asibuo, J. W., Akromah, R., Kantanka, S., Dapaah, O., Hanskofi, A., Dapaah, O. and Agyeman, A. (2008). Inheritance of fresh seed dormancy in groundnut. African J. Biotechnol., 7 (4): 421-424.

Bewley,J. D. (1997). Seed Germination and Dormancy. Plant Cell, 9(7): 1055-1066.

Bhapkar, D. G., Patil, P. S. and Patil, V. A. (1986). Dormancy in groundnut - a review. J. Maharashtra Agric. Univ., 11(1): 68-71.

Cochran, W. G. and Cox, G. M. (1957). Experimental Designs, $2^{\text {nd }}$ edition. Wiley, New York.

Francoise, C., Xia, Q., Bailly, C. and Bouteau, H. (2014). Ethylene, a key factor in the regulation of seed dormancy. Front Plant Sci., 5: 539-542.

Hull, F. H. (1937). Fla. Arg. Exp. Station
Tech. Bull., 314.

Gomaze, K. A. and Gomaze, A. (1976). Data transformation In: Statistical procedures for agricultural research. A Wileyintersclence Publication, John Wiley \& Sons, New York. Pp. 299-310.

Gowda, B. and Reddy, N. (2008). Storage of rabi or summer groundnut with desiccants to prolong seed viability and seedling vigour. Karnataka J. Agric. Sci., 21(3): 353-356.

Gowda, K. S. (2014). Studies on induction of seed dormancy and its effect on seed quality in groundnut CV. KCG-2.An unpublished M. Sc. (Agri.) thesis, submitted to University of Agricultural Science, Banglore, Karnataka, India.

Janila, P., Nagesh, P., Manohar, S. S. and Nigam, S. (2013). Variability for seed germination and seedling vigour in aging groundnut (Arachis hypogaea L.) seeds after storage under ambient conditions. J. Oilseeds Res., 30(2): 127133.

John, C. M., Seshadri, C. R. and Rao, M. B. (1948). Dormancy of the seed in groundnut. Madras Agril. J., 35:159167.

Ketring, D. L and Morgan, P. W. (1971). Regulation of dormancy in Virginia type peanut seeds. Plant Physiol., 45: 268-273.

Ketring, D. L. and Morgan, P. W. (1972). Role of endogenous ethylene and inhibitory regulators during natural ripening of dormant Virginia-type peanut seeds. Plant Physiol. 50: 382387.

Mahesh, C. G. (2007). Effect of seed source, growing season and genotypes on seed yield and quality in groundnut (Arachis hypogaea L.). An unpublished $M$. Sc (Agri.) thesis, submitted to University of Agricultural Science, Dharwad, Karnataka, India.

Maiti, R. K., Vidyasagar, P., Shahapur, S. C., 
Ghosh, S. K. and Seiler, G. J. (2006). Development and standardization of a simple technique for breaking seed dormancy in sunflower (Helianthus annuus L.). Helia., 29(45): 117-126.

Manonmani, (2002). Storability of dormant and non-dormant cultivars of groundnut. Seed Res.,30(1): 158-160.

Mather, R. K. and Manivel, P. (2000). Components analysis of bunch groundnut (ArachishypogaeaL.) germplasm from Sri Lanka. Tropic. Agri., 70: 256-259.

Meena, M. K., Chetti, M. B. and Nawalagatti, C. M. (2017). Influence of Different Packaging Materials and Storage Conditions on the Seed Quality Parameters of Groundnut (Arachis hypogaea L.). Int. J. Pure App. Biosci., 5(1): 933-941.

Meharunnisanarejo; Mohammad Ibrahim Keerio; Vajantimala; Pahoja and Aisha narejo. (2012). Effect of different methods of breaking seed dormancy in sunflower (Helianthus annuusL.). Sci. Intl., 24(4): 471-474.

Nautiyal, P.C., Bandyopadhyay, A. and Ravindra, V. (1993). Problems with defining seed dormancy characteristics of groundnut genotypes. J. Oilseed Res., 10: 271-276.

Nautiyal, P.C., Ravindra, V. and Misra, J. B. (1996). Fresh seed dormancy in Spanish type groundnut. Research accomplishments, Dept. of Plant Physiology, NRC on groundnut, Junagarh (Gj), India. Pp. 63-69.

Reddy, S. B. and Swamy, P. M. (1979). Abscisic Acid-Like Inhibitors and
Cytokinins in the Developing Seeds of Dormant and Non-Dormant Varieties of Peanut (Arachis hypogea L.). J. Exp. Botany, 30(1): 37-42.

Sebastian, A. (2014).Studies on seed dormancy in foxtail and proso millet genotypes. An unpublished M. Sc. (Agri.) thesis, submitted to University of Agricultural Sciences, Dharwad, Karnataka, India.

Sreeramulu, N. (1974). Changes in endogenous growth regulating compounds during the after ripening of the dormant seeds of groundnut. Int. J. plant physiol., 71(2): 101-107.

Swain, S. K., Sahoo, P. and Patnaik, M. C. (2002). A comparative analysis of dormancy pattern in the varietal forms of groundnut. J. Oilseeds Res., 19(2): 223-225.

Toole, T. K., Bailey, W. K. and Toole, E. H. (1961). Factors Influencing Dormancy of Peanut Seeds. Plant Physiol., 36: 663-71.

Vujakovic, M., Radic, V., Miklic, V., Jovicic, D., Balesevic, T. S., Mrđa, J. and Skoric, D. (2012). Seed dormancy of hybrids and parent lines of sunflower (Helianthus annuus L.). Helia, 35(56):111-118.

Wang. M. L., Chen. C. Y., Pinnow. D. L., Barkley, N. A. (2012). Seed dormancy variability in the U.S. Peanut mini-core collection. Res. J. Seed sci., 5(3):84-95.

Yadav, V. B., Bharud, R.W. and Nagawade, D. R. (2014). Effect of storage on quality of groundnut (Arachis hypogaea L.) seeds. J. Food Leg., 27(1): 17-23.

\section{How to cite this article:}

Deepthi Rajan, Rajiv Kumar, K. Devyani and Ramya, M. J. 2020. Role of Ethrel and Storage in Dormancy Breaking in Groundnut (Arachis hypogaea L.). Int.J.Curr.Microbiol.App.Sci. 9(02): 2550-2564. doi: https://doi.org/10.20546/ijcmas.2020.902.291 